\title{
International Law and Environmental Justice
}

\author{
Mehdi Abasi Sarmadi \\ Assistant Professor, Kharazmi University, Law and Political Sciences Department
}

\section{Reza Asadi Khomami}

Master degree in international law, University of Guilan, Department of law

\author{
Mahnaz Hajgozari
}

Master degree in international law, University of Guilan, Department of law

\section{Doi:10.5901/ajis.2013.v2n9p504}

\begin{abstract}
Universal declaration of human rights with emphasis on Non-discrimination between people and right on food for all, struggle to distribute justice for human. Live in healthy environment is one of fundamental rights for human But the development of civilization, especially since the industrial revolution accelerated the degradation of the environment. Human efforts to protect the environment have intensified since the late twentieth century but most of them have focused on prevention environment destruction rather than its influences on human. Focusing of environmental treaties instead of preventing damage to people, restrict harmful behavior for environment. Similarly, principles of international environmental laws are prevention of Damage to the environment and responsibility for its compensation. In contrast, international human rights completely focus on human; nevertheless, only in two human rights treaties, the right to a healthy environment, are binding. There are no mechanisms for Compensation for victims of human rights violations. Distribution of the sources of pollutants in the world is indicative environmental injustice. Not only in the world but also in the inside of countries, the sources of pollutants are closer to areas which people of color and lower income live. Some believe that environmentalism as new form of imperialism is formed in which developed countries are trying to impose their preferences and priorities concerning environment to developing countries. Also World Bank and IMF impose to developing countries to accept wastes which are exported by developed countries and accept polluter industries in their countries. Environmental justice in connection with procedural justice and political justice are issues that can investigate these claims. This article examines the lack of binding Law or judicial procedure in international law to compensate victims of environmental injustice especially in peace time and discusses Legal remedies in international law against environmentalism in relation with taxonomy of environmental justice.
\end{abstract}

Keywords: environmental justice, distributed justice, compensation, International human right, international environment law, environmentalism, source of pollutant

\section{Introduction}

Industrial development after industrial revolution lead to profiting of natural resources without notification to its harmful effects on environment. Increasing in industrial production beget wastes and harmful materials which holding of it make serious harmful damages for people and environment. Bury of polluted materials in industrial countries because of their harmful effect on people, caused many protests against governments and multinational companies. For this reason, some industrial countries export injurious wastes to developing countries. At that time subject of environmental justice become mooted.

In this essay explain about definition of justice in different doctrines in law with emphasize on positive law and the rights of people on food and healthy environment. Than express about duties of governments in protection of environment and state's responsibility. In other chapter explain about taxonomy of environmental justice and remedies which exist in international law in relation of environmental justice with a glance to ambiguities and shortcomings on this legal instrument. Finally, legal suggestion accompany with increasing sanction of international law for investigation to environmental injustice that happens in international community is presented. 


\section{Justice and law}

Human seeks justice and Rule of law has the tendency to bring justice. The concept of justice differs in different doctrines. Individualists believe that the concept of justice is equality and Proportion of profits and losses resulting from transactions. So law must provide basis of balancing between the goods which are exchanged without attention to ability and requirement of people. This kind of justice in result of respecting to contracts is created spontaneously and government has not any role in distributing wealth and merits assessment. It means justice as Aristotle said, is exchangeable justice. Individualists believe that whatever two party willing, will be justly so if freedom in contracting and will health provided, justice will observe and complain dose not remain. Convention of the market to artificially mechanism of non-economic impose and mechanism of unequal exchange that governing on the business, indicative that this doctrine is not appropriate to the current time. On the other side sociological positivism government as beneficiary interfere in wealth imperiously. The main object of justice in this doctrine is distributive justice. Aristotle is credited and explained it as "the distribution of honor, wealth, and other divisible of the community, which may be allotted among its members." ${ }^{1}$ Distributive justice calls for the fair allocation of the benefits and burdens of natural resource exploitation among and within nations. Also it has been defined as "the right to equal treatment, that is, to the same distribution of goods and opportunities as anyone else has or is given." 2 It is also one of the four-part definitions of environmental justice that will be explained in Taxonomy of Environmental Justice. It seems to us both Individual and community are reality and the aim of law must be keeping the human personality and providing the public interest at the same time. So justice is creating a balance between individual and social benefits. Justice is an interactive and collective concept so that the freedoms of everybody don't hurt to profits and freedoms of others.

\subsection{Responsibility of states}

During centuries people have been in searching of justice and the result of Years of struggle, manifested in universal declaration of human rights .non - discrimination between people, right on food and living in healthy environment are some of fundamental rights for human that have been emphasized in declaration. The Industrial Revolution and development of civilization changed the circumstance of life and new activity for better life accompanied with some problems for people and environment. Some people for gaining more benefits and welfare act to Actions that were dangerous to society. It caused one of contemporary important developments in civil rights, Principle of responsibility for risk that whereby everybody for profit or welfare effectuates any dangerous act, will be responsible for any accident caused by it, even if cannot attributed any error or omission to him. The theory is also extended to international law. Base of responsibility is only Cause and effect relationship and causation between action and created risk. In fact in distributive justice, in society if any one makes profit and welfare others must take advantages too. In international society, in performing their legal procedures states have not full freedom and are obliged to compensate an injury to others. Basis and origin of international responsibility is two doctrine; theory of fault and theory of risk. According to theory of fault, Act or refrain from acting In opposition to international rules is not enough for international responsibility and it needs fault or carelessness happens too. In conformity with theory of risk any breach or neglect of international rule, cause international responsibility. For example in case of trial smelter in investigation of U.S.A. claim against Canada, for the reason that smoke of steel and cast iron factory polluted Washington State, court of arbitration prescribed in its verdict: if smoke or other pollutions form one country have bad results in the neighboring country, the state that pollutions come from it territory, is responsible for the damages caused by it. The court without any investigation about Canada's fault identified Canada as responsible for this pollution. Responsibility of Canada was merely because of Causal relationship between smoking and entered loss due to activity of factory. It appears that international society tends to theory of risk. UN international law commission usually uses clearer and more objective Vocabulary such as" Wrongful act or behavior" but in all it tends to theory of risk too. In parallel of recognition of classic international responsibility, a new theory about international responsibility is mooted. It is theory of responsibility for non prohibited acts. In spite of theories of risk and fault which according to them obligation to compensation is a secondary, minor and intermediary characteristic, namely at

\footnotetext{
${ }^{1}$ Aristotle: The Nichomachean Ethics, Book V 267 (H.Rackham trans., Cambridge Univ. Press 1982). Relying on Aristotle's definition of distributive justice, some philosophers argue that "a political authority must define and particularize the scope or criterion of any scheme of distribution." Ernest J. Weinrib, Legal Formalism: On the Immanent Rationality of Law, 97 Yale L.J. 949,989 (1988).

${ }^{2}$ Ronald Dworkin, Taking Rights Seriously 273 (1977).
} 
first an international obligation must be breached than responsibility occur, in this theory compensation and reparation is a primary obligation and it is not pending to previous fulfillment of an international unlawful act. In the other word, merely sustained injury from one country to another will be caused responsibility although the done act or behavior was permitted by international law. In common law legal literature it calls "liability".

With generalization of these theories to international environment law, Brief description is needed:

At first, demolition of environment, within the borders of a country, if do not possess Trans-boundary influence will not cause international responsibility. In the second place, in international environment law, in international responsibility; fault is not the only determined element, in the other word, committing separate dangerous acts also cause international responsibility for states. As a result loss whether is a result from normal act of a factory or be result of breach an obligation the liability of the applier of damage is undeniable. In the other word, Regardless of origin of damage to environment in other countries (fault or risk), states are responsible in front of damage. The liability to pay compensation by contaminated government is the most important principle on the subject of international environmental responsibility for states.

\section{Environmentalism}

When Twenty-First century started, the body of human rights law joined on the international scene by a growing body of international environmental law. It was as a result of development of international law and human rights. Apparently it seems these two influential areas of law have different aims and objectives but protection of environment is in line with preservation of human rights. The reason for this assumption is that Live in healthy environment is one of fundamental rights for human and clean water and clean air are the most important elements for human life. for example in introduction of Agenda 21 in section 1 emphasize on unequal situations between countries and lack of health, illiteracy and poverty Is deteriorating also the section 20 of Agenda 21 is about Hazardous wastes and expresses about a kind of questionable new trades, namely transfer of these materials to developing countries. Although Bamako treaty concluded as a defensive measure to prevent entry of hazardous wastes to Africa, but all developing countries are pressurized by developed countries for accepting them. For this reason environmental justice would be understandable. Concept of environmental justice may differ in international, national, and local scope; this article notice to international aspect of it. At the international level claims that governments and multinational corporations are exploiting native peoples and the impoverished conditions of developing nations. The United States Environmental Protection Agency (EPA) defined "Environmental justice" as the fair treatment and meaningful involvement of all people, regardless of race, color, national origin, culture, education or income, with respect to the development, implementation and enforcement of environmental laws, regulations and policies. ${ }^{3}$ Also professor Bunyan Bryant defines environmental justice as referring " to those cultural norms and values,rules, regulations, behaviors, policies, and decisions to support sustainable communities, where people can interact with confidence that their environment is safe,nurtuting, and protective."4

For example imagine a developing country with oil resources. In developing countries usually environmental regulations are well-developed but enforcement of them is minimal. Oil companies, for more benefits, using this lax enforcement to employ less expensive but environmentally unsound practices. With creating open waste pits and flare huge quantities of natural gas, leak of harmful materials will started. Consequently sever land pollution results and drinking water becomes unsafe. Domestic animals die and community members experience a variety of health problems. This is exactly what happened to the oil extraction in the Caspian Sea. This sea In terms of fisheries, climate and economic is very important for people of South Coast of Caspian sea in Iran. Entry 122 thousand tons of oil pollution in the Caspian Sea such 304 tons cadmium and 34 tons lead per year, cause increasing pollution in Caspian Sea .with notice to this point that 16 of petroleum derivatives are carcinogenic, Danger that threatens the South Coast people become distinct. ${ }^{5}$

One of coastal countries in Caspian Sea regardless of the environmental benefits of other countries action to extraction of oil in Caspian Sea without observance needed standards for environment protection that devastating effects of it, mentioned above. Considering the harmful effects of non standard operations in oil extraction on fishery and health of people who live in coast of the sea, can explicitly claim that an environmental injustice is happening. The same

\footnotetext{
${ }^{3}$ Definition available at: http://www.epa.gov=compliance=resources=faqs=ej=index.html \#faq1> (last accessed 16 April 2007).

${ }_{4}^{4}$ Bunyan Bryant, Introduction, in Environmental Justice: Issues, Policies, and Solutions 1, 6 (Bunyan Bryant ed., 1995).

${ }^{5}$ Director of Research Institute of Caspian Sea with Shargh newspaper 10 may 2011
} 
behaviors were done in recent decades, for example in august 2006 by A Dutch Company with income equivalent 28 billion dollars, buried 500 tons of toxic waste in the Ivory Coast in West Africa because it did not want to pay the \$ 250,000 cost of eliminating it in the Netherlands At least 10 people died as a result of inhaling the stench, 69 people were hospitalized and more than 100 thousand people to the health care they need. ${ }^{6}$ And another example, by reports that a Taiwan plastics company, unable to find a location in Taiwan to dispose of its mercury wastes, shipped the hazardous waste to Cambodia, where it ended up in an open pit, killing a local worker and threatening water supplies. ${ }^{7}$ Lawrence Summers, now Secretary of the Treasury in the Clinton Administration, argued that, regardless of distributive justice concerns, the World Bank should encourage more exportation of waste to the least-developed countries: "I think the economic logic behind dumping a load of toxic waste in the lowest-wage country is impeccable and we should face up to

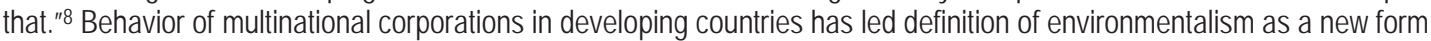
of imperialism, whereby the rich, developed countries impose their environmental preferences and priorities on the poor, developing countries. Using two kernel of truth, they obscure the relationship among free trade, environmental protection and social justice. First one is that Wealthy countries said that environmental protection is a luxury that developing countries can ill afford and second one is that industrialized countries have generally played a leadership role in the protection of the global environment. This claim is confirmed by the behavior of some big companies. Is there any Deterrent natural feedback mechanism in this Chaos Trade market?

\subsection{Environmental Justice}

Environmental justice in four-part is classified; (1) distributive justice ;(2) procedural justice; (3) corrective justice; and (4) social justice. For understanding the meaning of aspects of environmental justice have to refer to the definitions made by scholars. Dr. Bullard identifies distributed justice as "geographic equity" referring to the location and spatial configuration of communities and their proximity to unwanted land uses. ${ }^{9}$ The Principles of Environmental Justice address distributive justice when demanding that all peoples be free from any form of discrimination and calling for universal protection from, and the cessation of the production of, harmful materials and wastes. ${ }^{10}$ Distributive inequities not include only threats from pollution or the loss of natural resources. Noise, odors, blowing trash, aesthetic concerns, increased traffic, termites, decreased property values and uses, fires, accidents, psychological harm, and other nuisance or quality-of-life impacts also may support a claim of distributive injustice. ${ }^{11}$

Aristotle referred to procedural justice as a status in which individuals have an "equal share in ruling and being ruled"12 fairness of decision-making process is one of its aspects. This aspect of environmental justice is termed "procedural equity" by Dr. Bullard. ${ }^{13}$ and professor Kaswan refers to it as "political justice" it means achieving environmental justice will require changing the political dynamic so all groups are treated fairly in decision making processes. ${ }^{14}$ Must be notice that the fair outcome is more important than participation in a process. Governments should be obliged to collect and analyzes data on environmental exposures and public health and help to forming decision making processes with equitable out come.

\footnotetext{
6 Dixon Norm, Change the System- Not the Climate, Green Left Weekly, January 26, 2007

7 What toDoWith all that Waste? Bus.Wk, Jan. 18, 1999, at 26.

8 Let Them Eat Pollution, Economist, Feb.8, 1992.at66.

${ }^{9}$ Bullard, Overcoming Racism in Environmental Decisionmaking, supra note 1, at 13; Bullard, Dumping in Dixie, supra note 1 , at 116.

10 20. Principles of Environmental Justice, supra note 12, at nos. 2, 4, 6.

${ }^{11}$ See, e.g., North Baton Rouge Envtl. Ass'n et al., Complaint Under Title VI of the Civil Rights Act, No. 10R-97-R9 (June 8, 1998) (alleging broad range of nuisance and quality of life impacts from proposed landfill in Alsen, Louisiana); see also Office of Civil Rights, U.S. EPA, Draft Revised Guidance for Investigating Title VI Administrative Complaints Challenging Permits §VI.B.2.a \& app. A (June 2000) (adverse impacts, or "stressors," may include physical factors such as noise and odors), reprinted in 65 Fed. Reg. 39649 (June 27, 2000) (available from the ELR Document Service, ELR Order No. AD-4516) [hereinafter Draft Revised Title VI Guidance].

12 Steven J. Heyman, Aristotle on Political Justice, 77 Iowa L. Rev. 851, 863 (1992); see also Aristotle, Politics III.13 (Carnes Lorde trans., 1984).

${ }^{13}$ Bullard, Dumping in Dixie, supra note 1, at 116; U.S. EPA, Guidance for Incorporating Environmental Justice Concerns in EPA'sNEPACompliance Analysis 42-43 (1998) (explaining the characteristics of Dr. Bullard's public involvement strategies) (available from the ELR Document Service, ELR OrderNo. AD-3856); Bullard, Overcoming Racism in Environmental Decisionmaking, supra note 1, at 12.

14 Kaswan, supra note 1, at 224.
} 
Corrective justice is third aspect of environmental justice which involves fairness in the way punishments for law breaking when damages inflict on individuals and communities are mooted. Aristotle referred to this aspect of justice as "rectificatory" as "it treats the parties as equals and asks only whether one has done and the other suffered wrong, and whether one has done and the other has suffered damage"; if so, it attempts to restore the victim to the condition she was in before the unjust activity occurred. ${ }^{15}$

Corrective justice includes the concepts of "retributive justice,"16 "compensatory justice,"17 "restorative justice,"18 and "commutative justice." ${ }^{\text {"19 }}$ And forth aspect of environmental justice is social justice that defines as "that branch of the virtue of justice that moves us to use our best efforts to bring about a more just ordering of society—one in which people's needs are more fully met."20 "The demands of social justice are . . f first, that the members of every class have enough resources and enough power to live as befits human beings, and second, that the privileged classes, whoever they are, be accountable to the wider society for the way they use their advantages." ${ }^{21}$

\section{Environmental justice and International Environmental law}

Nowadays, the most International Environmental agreements including global and regional treaties about environment like final declaration of RIO conference and the agenda 21 pay special attention to responsibility of states in protection of environment. In 1992 United Nations Conference on Environment and Development (UNCED) produced agenda 21 which is an voluntarily implemented action plan but non-binding Helsinki Rules in1966 emphasize "prevent any new form of water pollution or any increase in the current levels of pollution which cause substantial damage to shared water between states" is duty of member states. In article 3 of Montreal Rules regarding enforcement international law of crossborder pollution are mentioned "states are committed to prevent and reduce of cross border pollutions and care of it, so that do not cause damage to the environment and land of other states "also In article 30 of Charter of economic rights and duties of states 3281 (XXIX) which approved in 29 session of General Assembly of UN is mentioned:" the protection, preservation and enhancement of the environment for the present and future generations is the responsibility of all states. All states shall endeavor to establish their own environmental and developmental policies In conformity with such responsibility. The environmental policies of all states should enhance and not adversely affect the present and future development potential of developing countries. All states have the responsibility to ensure that activities within their jurisdiction or control do not cause damage to the environment of other states or of areas beyond the limit of national jurisdiction. All states should cooperate in evolving international norms and regulations in the field of environment. All these represent a global commitment to protect the environment; however we must consider that With the exception of a few of multilateral treaties that have been established characters for the monitoring of environmental violations, ${ }^{22}$

\footnotetext{
${ }^{15}$ Ellen Frankel Paul, Set-Asides, Reparations and Compensatory Justice, in Nomos XXXIII: Compensatory Justice 97, 100-01 (John W. Chapman ed., 1991) (citing Aristotle, Nicomachean Ethics,1132 a, 4-7 (Martin Ostwald trans., 1962)).

${ }^{16}$ Norman E. Bowie, Towards a New Theory of Distributive Justice 4 (1971). The concept of retributive justice is reflected in the notion "that fairness to citizens who make sacrifices by obeying the law requires that violators be punished rather than reap benefits for disregarding legal standards." Kent Greenawalt, Punishment, 74 J. Crim. L. \& Criminology 343, 349 (1983).

17 Paul, supra note 119, at 102-03; Been, supra note 60 , at 1047 \& n.248. Compensatory justice attempts "to bring the victim to the condition he would have been in, or its equivalent, had the injurious event never occurred." Paul, supra note 119, at 103.

${ }^{18}$ Richard O. Brooks, A New Agenda for Modern Environmental Law, 6 J. Envtl. L. \& Litig. 1, 27 (1991). Professor Brooks distinguishes corrective justice (correction of environmental abuses) from retributive justice (retribution or punishment for environmental abuses or violations) and restorative justice (the fair restoration of nature). Id.; see also Thomas M. Hoban \& Richard O. Brooks, Green Justice: The Environment and the Courts 167-68 (1996). Aristotle's rectificatory justice is also restorative in that "it attempts to restore the victim to the condition he was in before the unjust activity occurred." Paul, supra note 119, at 101.

${ }^{19}$ See Taylor; supra note 1, at 537. According to Professor Taylor, "corrective or commutative justice" is "concerned with the way individuals are treated during a social transaction." Id.; see also John Finnis, Natural Law and Natural Rights 177-84 (1980) (tracing the origins of and explaining the term "commutative justice").

20 Robert E. Rodes Jr., Social Justice and Liberation, 71 Notre Dame L. Rev. 619, 620 (1996).

${ }^{21} \mathrm{Id}$. at 626 . Rodes observe that efforts to reform unjust institutions and achieve social justice give rise to a class struggle: "The victims have a stake in reform, while the beneficiaries have an equal stake in the status quo." Id. at 624.

${ }^{22}$ see : Montreal Protocol on Substance that Deplete the Ozone Layer,Sept.16,1987,1522 U.N.T.S.451,reprinted in 26 I.L.M 1541;United Nations Framework Convention on Climate Change, May 9,1992,reprinted in 31 I.L.M.849(entered into force March 21,1994) ; Convention on Long-Range Tran boundary Air Pollution ,Nov.13,1979,34 U.S.T.3043 U.N.T.S. 217,(entered into force March 16<1983); Basal Convention,supra note 21; Convention on the Prevention of Marine Pollution by Dumping of Wastes and Other Matter,supra note 20
} 
resolutions of general assembly and other treaties about environment are soft law so they are not mandatory. As mentioned above, we study aspects of environmental justice in international community therefore must study it in frame work of international law. We have in mind two categories; responsibility of states and international environment law in regard to Caspian Sea responsible of states is disputable because Caspian Sea is common between five countries. Iran plans to act on treaties of 1921 and 1940 but these treaties have not mentioned of how to use the resources of the sea bed. Also base on the 1982 convention of Sea law, lakes are not covered by this convention and the legal regime of lake must be originated by coastal states but landscape of legal regime of Caspian Sea is hazy. Hence Environmental issues have been overshadowed by political issues because of all states lean to use seabed resourses.As a result there is no treaty between coastal countries about protection of environment of Caspian sea which breach of it cause state responsibility. Therefore no legal authorities are available for People who have suffered from a non-standard oil extraction. In cases like Cambodia and Ivory Coast in West Africa, subject is in the domain of Private Law and because of Multinational companies are not follower of international law and treaty between a multinational company and state if it do not include a breach of international law, don't cause responsibility for state.

\subsection{Remedies of International Law in relation of sanction of Law}

Abstaining from environmental degradation that threatens the right to life is a fundamental norm of customary international law; nevertheless, international law lacks sufficient means to compensate actions which are detrimental to the environment. Because being efficacious of environmental regulations due to their global nature requires international cooperation. In the global level no jurisdiction court with compulsory competent or supervising or license of execution the rules of transformative international environmental law, has been established. In the other side, although International Court of Justice has competence to investigation to environment disputes, but in past forty years no claims have been investigated while that its competence is limited to states disputes and individuals, companies and other NGOs have not capacity to claim in ICJ. In part related to international criminal law, although in draft of international law commission concerning responsibility of states express in article 19(d) "serious breach of international obligation that for protection and preservation of human environment possess of greatest importance" is international crime ${ }^{23}$, charter of ICC about investigation to environmental claims remain silent. ${ }^{24}$ In absence of an international investigator reference for environmental crimes ; The rich developed countries, because of having more shares in world's economy and its powerful political effects, dominate decision-making in the International Monetary Fund (IMF), the World Bank, the World Trade Organization (WTO), and multilateral environmental treaty assemblies. While they can present alternatives points of view, the preferences of the powerful generally dictate the substantive outcomes. ${ }^{25}$

\section{Conclusion}

International environmental law may not be able to address all of environmental injustices challenges anytime soon. Regrettably, the discourse of international environmental law is often technocratic and

Unhistorical. Revise in international environmental law with justice at its core may facilitate the development of international environmental regimes that are more effective and more responsive to the inequities in global resource allocation. Also it seems to us competence in adjudication claims mooted by NGOs, worker's syndicates, racial and regional unions about environmental injustice must be added to charters of ICC and ICJ. Another alternative is organizing an International tribunal to deal with environmental offenses with competence in adjudication claims mooted by private and general individuals .claims must be about environmental damages So that the whole community benefits affect. Also court can obligate public prosecutor to investigate problems of international environment. States, individuals, regional unions and NGOs would have the capacity for litigation to public prosecutor. Creating an international court will straighten

${ }^{23}$ Report Of The International Law Commission on The work of its thirty-second session,U.N. GAOR,35th sess.,supp. No.10,at 1,Un .Doc A/35/10(1980), Reprinted in [1980]2 Y.B. Int'il. com'n 5 U.N. doc. A/CN. 4/Ser.A/1980/Add.1 (part2)

${ }^{24}$ Rome Statute of the International Criminal Court, UN. Diplomatic Conference of Plenipotentiaries on the Establishment of an International Criminal Court, art.22, U.N. Doc. A/Conf.18319, at 21(1998)

${ }^{25}$ See, Anand, op. cit., pp. 132-33; P. Hossay, Unsustainable: A Primer for Global Environmental and Social Justice, London and New York: Zed Books, 2006, pp. 191-98; R. Peet, Unholy Trinity: The IMF, World Bank and WTO. London and New York: Zed Books, 2003, pp. 200-04. 
motivations of supporting the protection of environment and increase availability of efficient judicial mechanisms at the global level.

\section{References}

Ako, Rhuks T,"Nigeria's Land Use Act: An Anti - Thesis To Environmental Justice", Journal Of African Law, 53, 2(2009), pp. 289-304 @ School of Oriental and African Studies.doi:10.1017/S0021855309990076 printed in the United Kingdom

Gonzalez ,Carmen G. , "Environmental Justice And International Environmental Law", Seattle University school of Law ,Legal paper , series \#12-11

Gonzalez ,Carmen G. , "The Global Food Crisis: Law,Policy,and The Elusive Quest For Justice",Seattle University School of Law, Legal Paper

Kuehn,Robert R. ," A Taxonomy of Environmental Justice", Environmental Law Reporter,Vol:30,p.10681,2000

Katozian,Amir N.,"Introdduction To science Law" ,Enteshar Company, edition 1,print 81,2012

Mccallion,Kenneth F.,"International Environmental Justice: Rights and Remedies", Hasting International and Comparative law Review, Vol.26,Number 3,spring 2003,University of California PP.427-437

Osofsky,Hari M.," Learning From Environmental Justice: A New Model For International Environmental Rights", Stanford Environmental Law Journal ,1/2/2005

Wani,Ibrahim J,"Poverty Governance, The Rule of Law and International Environmentalism: A Critique of Basel Convention On Hazardous Wasts,1 Kan,J.L.\& Pub.pol'y 37,38 (1991)

Ziai Bigdeli,Mohhamad Reza,"Public International Law",Ganjedanesh publication,2008

http://www.un.org/esa/dsd/agenda21 